\title{
The preparation of composite solid fuels in the roll press
}

\author{
Bogdan Kosturkiewicz ${ }^{1, *}$, and Andrzej Janewicz ${ }^{1}$ \\ ${ }^{1}$ AGH University of Science and Technology, Faculty of Mechanical Engineering and Robotics, \\ 30-059 Kraków, al. Mickiewicza 30, Poland
}

\begin{abstract}
Directive 2009/28/EC of the European Parliament and of the Council of 23 April 2009 on the promotion of the use of energy from renewable sources and amending and subsequently repealing Directives 2001/77/EC and 2003/30/EC, and the annex to resolution 202/2009 of the Council of Ministers of 10 November 2009 on the energy policy of Poland until up to 2030 indicate the necessity of increasing the contribution of renewable fuels in the energy balance of Poland. This increase is supposed to strengthen Polish energy security. The undertakings of the Polish government indicate the increase in utilisation of various renewable energy sources such as biomass. Due to that, new technologies connected with the management of the traditional energy sources, such as lignite, have to be developed. Due to its high moisture, lignite is perceived as a lowefficiency fuel. The calorific value of lignite can be improved upon by mixing it with biomass, e.g. sawdust, and briquetting it in roll presses equipped with asymmetrical layout compacting system. Such technology can be used only if the mixed ingredients are adequately prepared beforehand. Research in this field has been conducted in the Department of Manufacturing Systems AGH University of Science and Technology in Cracow. Based on this research, PW 500 roll press design was prepared. PW 500 roll press is prepared for briquetting composite solid fuels based on a mixture of lignite extracted in Szczerców and two types of biomass: oat straws and spruce sawdust. The results of the aforementioned briquetting are presented in this article.
\end{abstract}

\section{Introduction}

In order to properly compile EU energy and climate policies as well as domestic economics development strategy, it must be considered that, in the long-term, Poland will be utilising both hard coal and lignite mined mostly on Polish soil. Even though it is estimated that the lignit's percentage contribution in net energy production should decrease by $10.10 \%$ by 2030 whereas hard coal's contribution should decrease by $2.77 \%$ in comparison with 2015 , those two fuels will still be responsible for Poland's energy security [1]. At the same time, due to forecasted increase in demand for electrical energy, the Ministry of Economy of the Republic of Poland has defined three scenarions for the aforementioned demand: low,

\footnotetext{
* Corresponding author: kostur@agh.edu.pl
} 
referential and high [1]. All three of which project an increase in the said demand. The first scenario projects an increase of $179 \mathrm{TWh}$, the referential one $204 \mathrm{TWh}$ and the high one $225 \mathrm{TWh}$. The final demand is projected to increase by $44.35 \%, 60.63 \%$ and $75.78 \%$ respectively in comparison with year 2015.

It should be noted that lignite is classified as a low-grade fuel due to high moisture, ash content and low calorific value [2]. Due to that, it seems reasonable to mix the lignite with different forms of biomass in order to increase, e.g., the calorific value. In the process, the aims presented in Directive 2009/28/EC of the European Parliament on the promotion of the use of energy from renewable sources are fulfilled and the emission of the harmful substances is reduced [3].

The Ministry of Economic Development of Poland developed in 2017 a new project, 'Program dla Śląska', which focuses on the importance of diversification of energy sources [4]. One of the aims of the project is to underline the importance of Śląskie Voivodeship in Poland's energy security and development of energy policies. Another goal of this project is to supervise and evaluate the competitiveness of Polish coal in comparison with coal imported from countries which are not controlled by the EU climate change policies [4]. One of the actions taken involve briquetting coal with biomass with high mechanical strength and calorific value. This undertaking, which can also be achieved by electrostatic desulphurisation of flue-gas, aims at reducing environmental pollution (i.a. low-emission and dustiness) $[5,6]$.

Solid fuels management often requires densification of the materials. One of the waste material nodulising methods is briquetting it in roll presses. High efficiency, low energy consumption, construction compactness of the roll presses and durability of the components are merely some of the advantages of roll presses over stamp briquetting press. Research in the field of briquetting such solid fuels as: fine lignite, charcoal, hard coal coke as well as selected composite fuels has been conducted in the Department of Manufacturing Systems AGH University of Science and Technology in Cracow. The results of the said research have been presented in this article.

\section{Experimental}

Fine lignite from Czechian mine in Most-Komorany (P-1); fine charcoal made from coconut parings from Indonesia (P-2); hard coal coke 34 (P-3); and lignite (P-4) used as a base component for composite fuel (P-4a, P-4b, P-4c, P-4d) from 'Szczerców' mine near Bełchatów, Poland. The solid fuels had different chemical composition and different energetic parameters. The composite solid fuels consisted of lignite, spruce sawdust and oat straw. The fuel properties of all consolidated materials are shown in Table 1.

Table 1. Characteristics of the fuel properties of the consolidated materials.

\begin{tabular}{|c|c|c|c|c|}
\hline Solid fuel & $\begin{array}{c}\text { Calorific value } \\
\mathrm{Q}_{\mathrm{i}}^{\mathrm{r}} \mathrm{kJ} / \mathrm{kg}\end{array}$ & $\begin{array}{c}\text { Moisture } \\
\mathrm{W}_{\mathrm{t}}^{\mathrm{r}} \%\end{array}$ & $\begin{array}{c}\text { Ash } \\
\mathrm{A}^{\mathrm{r}}, \%\end{array}$ & $\begin{array}{c}\text { Sulfur } \\
\mathrm{S}^{\mathrm{r}}, \%\end{array}$ \\
\hline $\mathrm{P}-1$ & 20.202 & 4.7 & 5.8 & 1.40 \\
\hline $\mathrm{P}-2$ & 24.687 & 3.19 & 18.20 & 0.01 \\
\hline $\mathrm{P}-3$ & 31.375 & 11.8 & 7.8 & 0.46 \\
\hline $\mathrm{P}-4$ & 8.091 & 51.16 & 11.56 & 1.05 \\
\hline $\begin{array}{c}\text { Spruce } \\
\text { sawdust }\end{array}$ & 16.987 & 6.93 & 4.68 & 0.05 \\
\hline Oat straw & 16.453 & 7.10 & 4.82 & 0.09 \\
\hline
\end{tabular}


Briquetting of P-1 and P-2 fuels was conducted with addition of BORCET BRY 200 binder, whereas hard coal and composite fuels were briquetted without said addition. BORCET BRY 200 binder is a modified, non-toxic, biodegradable carbohydrate. P-3, P-4a, P-4b, P-4c and P-4d were also briquetted without the binder. The composite fuel's composition is presented in Table 2.

Table 2. Composite fuel composition.

\begin{tabular}{|c|c|c|c|}
\hline Composite fuel & $\begin{array}{c}\text { Brown coal, } \\
\text { \% by mass }\end{array}$ & $\begin{array}{c}\text { Spruce sawdust, } \\
\text { \% by mass }\end{array}$ & $\begin{array}{c}\text { Oat straw, } \\
\% \text { by mass }\end{array}$ \\
\hline P-4a & 70 & 15 & 15 \\
\hline P-4b & 85 & 15 & - \\
\hline P-4c & 85 & - & 15 \\
\hline P-4d & 70 & 30 & - \\
\hline
\end{tabular}

The briquetting of solid fuels was conducted in a laboratory roll press LPW 450 with the cylinders' diameter of $450 \mathrm{~mm}$. LPW roll press is equipped with a gravity feeder and is a part of an experimental plant as presented in Fig. 1.

Roll press LPW 450's main drive consists of a motor reducer Drive 6000 type CHHMS 30-6170-15/T F180MG/4 (with an asynchronous engine of PS $=22.0 \mathrm{~kW}$ and nominal rotational speed $n_{\mathrm{n}}=1440 \mathrm{rpm}(50 \mathrm{~Hz})$ and reducer type 'CYCLO' with gear ratio $\left.i_{\mathrm{c}}=15\right)$. The motor reducer's spigot was connected via flexible coupling to a pinion housing with a total gear ratio of $i_{\mathrm{r}}=6.43$ (which was also used in parting torque). Oldham's clutches were placed on the shafts' spigots of the pinion housing which allowed for the compensation of incommensurability of the shafts. Moreover, on one of the shafts there was a friction clutch allowing for an alignment of roll press forming cavities. Electronic control system of the engine's rotational speed consisted of a frequency converter FR 540 30K EC (MITSUBISHI ELECTRIC) and a FFR-A540-95A-SF100 filter. Such system, alongside the press' main drive, allowed for a smooth control of the roll press' rollers peripheral speed $v_{\mathrm{w}}$ in range $0-0.5 \mathrm{~m} / \mathrm{s}$. The data was gathered by the DAQ-700 National Instruments measurement system and a laptop. A specialistic system used in recording, processing and presenting the measured data was prepared in labVIEW.

Solid fuels P-1, P-2 and P-3 were unified in terms of physical-chemical characteristics and then dried in a mixer with preheated water jacket. BORCET binder, as well as water in appropriate ratio, was added to the P-1 and P-2 fuels ( $8 \%$ and $6 \%$ respectively). Everything was mixed for about 30 minutes in order to obtain partical size distribution as well as chemical homogeneity of the mixture. P-3 fuel was mixed with water only. The mixtures were placed in a hermetically sealed containers in order to keep constant moisture level of the mixtures. As for the composite fuels, the lignite was mixed with biomass and then dried in a mixer. The fuels prepared in a mixer were then placed in a roll press equipped with a gravity feeder and forming rings allowing for obtaining a saddle-shaped briquettes of 6.5 $\mathrm{cm}^{3}$ volume. Studies conducted in the Department of Manufacturing Systems confirmed the efficiency of using this type of asymmetrical layout compacting system for briquetting waste materials $[7,8,9,10]$. 


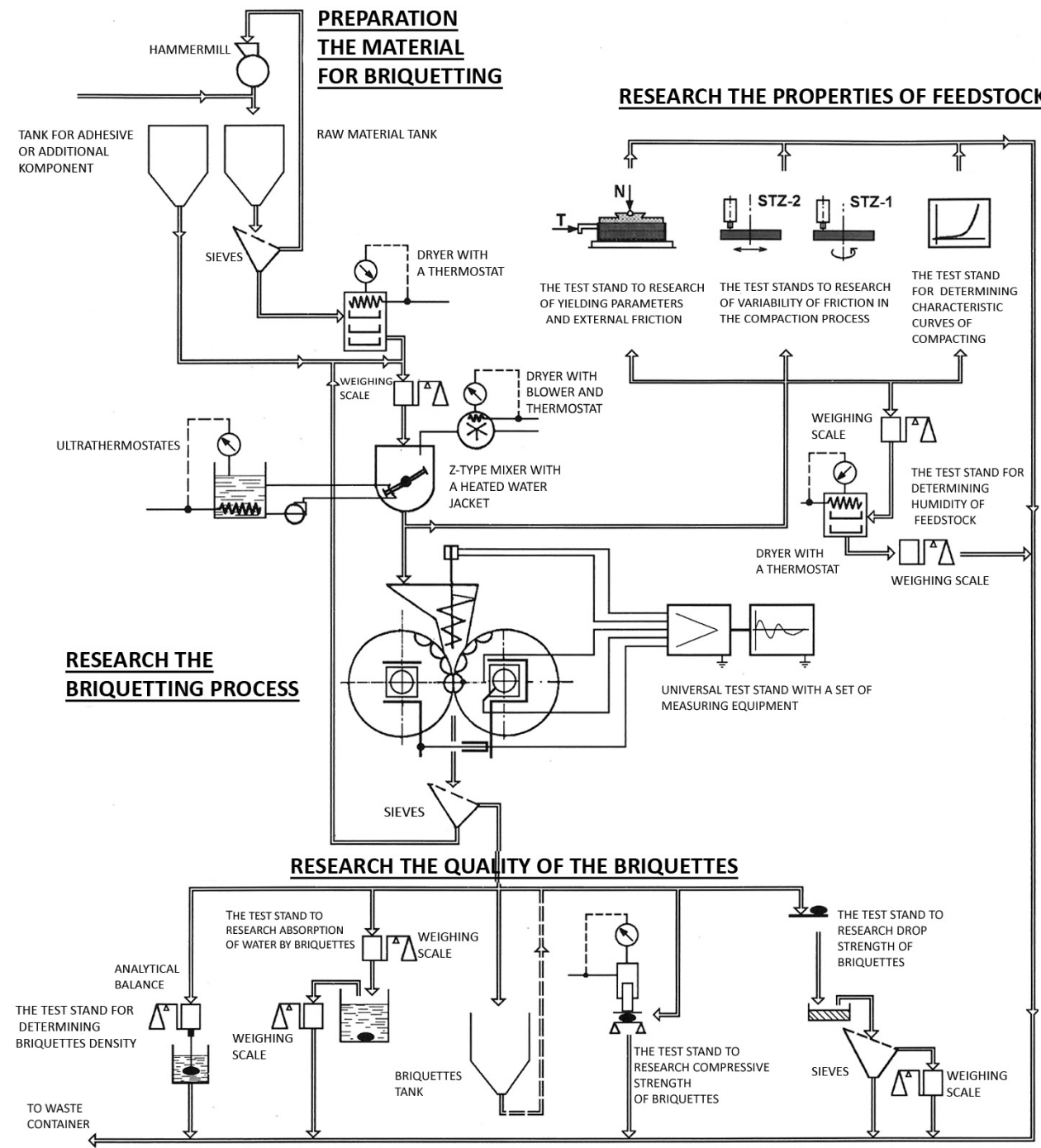

Fig. 1. Layout of the experimental plant used in briquetting fine-grained materials in a roll press.

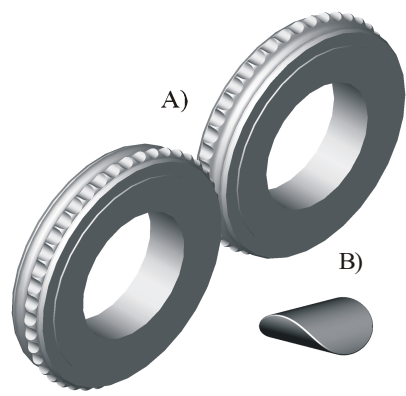

Fig. 2. Asymmetrical layout compacting system of laboratory roll press LPW 450 : A) rings, B) briquette. 
The amount of fine-grained solid fuels was $5-7 \mathrm{~kg}$. The sample was compacted at $0.1 \mathrm{~m} / \mathrm{s}$ of tangential velocity corresponding to rotational speed of $4.25 \mathrm{rpm}$. The initial value of the interspace between the rolls during briquetting process was $\mathrm{d} \sim 1.0 \mathrm{~mm}$. The briquettes were obtained in a shape presented in Fig. 3.

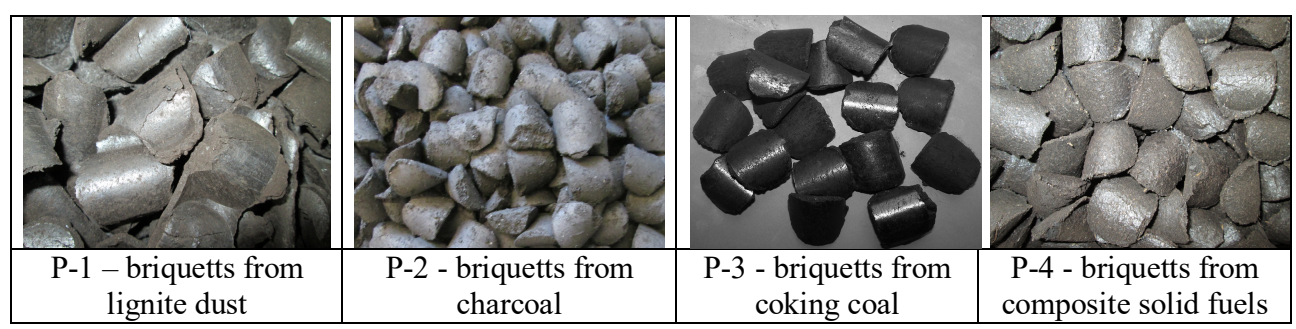

Fig. 3. Foto of briquettes made of solid fuels.

During the experiment, roll press torque $M_{\mathrm{w}}$, unitary pressure on roll press' cavity forming rings $p_{\mathrm{n}}$, interspace between the rolls $\delta$, drop strength measured directly after the $K_{0}$ try, drop strength measured after $168 \mathrm{~h} K_{168}$, compressive strength measured after $168 \mathrm{~h} D_{168}$ and briquettues' density $\rho_{\mathrm{b}}$ were measured. Due to high plasticity of the briquettes right after the production process, their compressive strength couldn't have been determined.

Bearing in mind past experiments $[11,12]$, compressive strength directly after the try of the briquettes was not measured. It was assumed that the newly formed briquettes would be ductile and the consolidation process would take place after seasoning. The methodology of determining the drop and compressive strengths is described in the literature review [13]. It allowed to determine the load resistance during the transhipment, transportation and thermal management of the briquettes. The roll press torque was measured in a measuring circuit which consisted of a telemetric system MT 2555A, preamplifier EV 2510A and Hottinger Baldwin Messtechnik amplifier KMN 602A. The measurements were helped by the Hottinger Baldwin Messtechnik strain gauges. The signal from the strain gauges was transmitted through a transducer and preamplifier receiver and then sent through a cable to the amplifier and registered on a laptop's hard drive. Fig. 4 presents a photo of a shaft of a laboratory roll press LPW 450 which was used in the measurement of the torque.

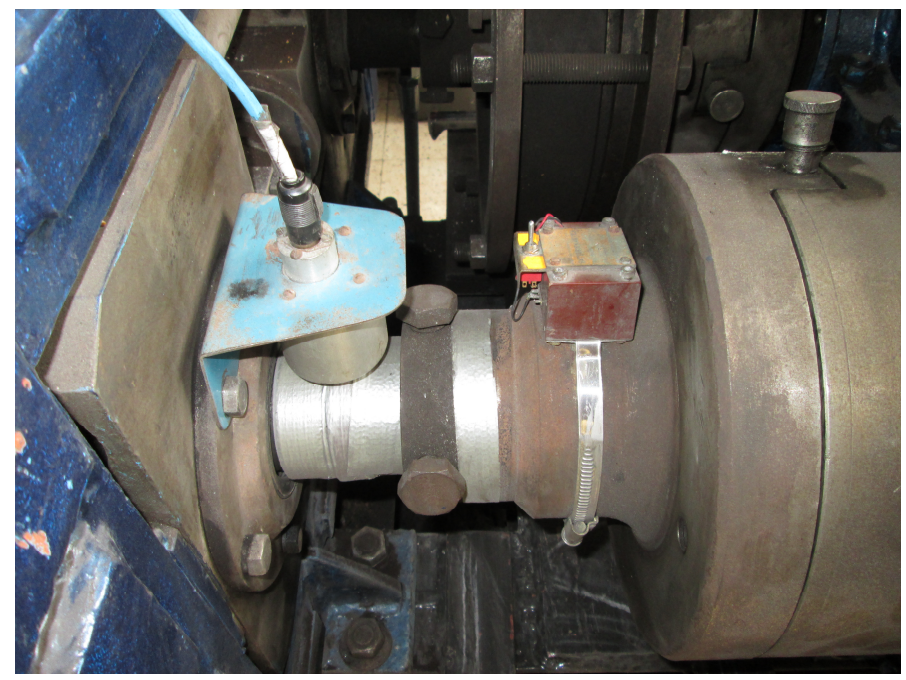

Fig. 4. The foto of the laboratory shaft of roll press on which the torque was measured. 


\section{Results}

The results have undergone a statistical treatment in accordance with estimation statistics (point estimation to be exact). The analysis allowed to determine the power consumption $N_{\mathrm{b}}$ during the briquetting process of the solid fuels as well as unit energy consumption $\mathrm{Z}_{\mathrm{e}}$ of the process. Power consumed during the briquetting process $N_{\mathrm{b}}$ was determined by the relation:

$$
N_{\mathrm{b}}=2 \cdot\left(M_{\mathrm{t}} \cdot n_{\mathrm{w}}\right) / 9.55, \mathrm{~kW}
$$

where: $M_{\mathrm{t}}$ - torque moment on a roll press, $\mathrm{kNm} ; n_{\mathrm{w}}$ - roll press rotational speed, rpm.

Roll press throughput (equipped with saddle-shaped forming cavity rings) $W_{\mathrm{b}}$ was determined by the relation:

$$
W_{\mathrm{b}}=60 \cdot V_{\mathrm{b}} i_{\mathrm{b}} n_{\mathrm{w}}, \mathrm{m}^{3} / \mathrm{h},
$$

where: $V_{\mathrm{b}}$ - briquette volume, $\mathrm{m}^{3} ; i_{\mathrm{b}}$ - cavities quantity, $i_{\mathrm{b}}=90 ; n_{\mathrm{w}}$ - roll press rotational speed, rpm.

Unit energy demand of briquetting process $\left(Z_{\mathrm{e}}\right)$ was determined by the equation:

$$
Z_{b}=N_{b} / W_{b}, \mathrm{kWh} / \mathrm{m}^{3} \text {, }
$$

where: $N_{\mathrm{b}}$ - power consumed during briquetting process, $\mathrm{kW} ; W_{\mathrm{b}}$ - roll press throughput, $\mathrm{m}^{3} / \mathrm{h}$.

Figures 5-7 present the strength results of briquettes made of composite solid fuels.

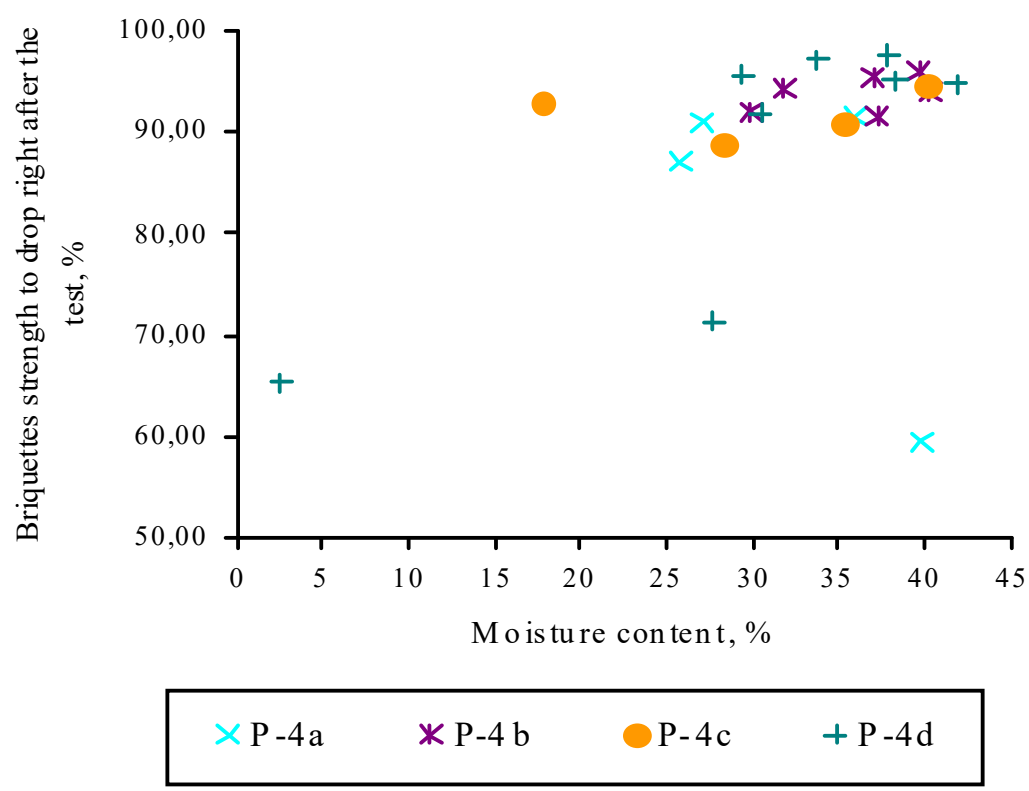

Fig. 5. Composite solid fuels briquettes strength to drop right after the test. 


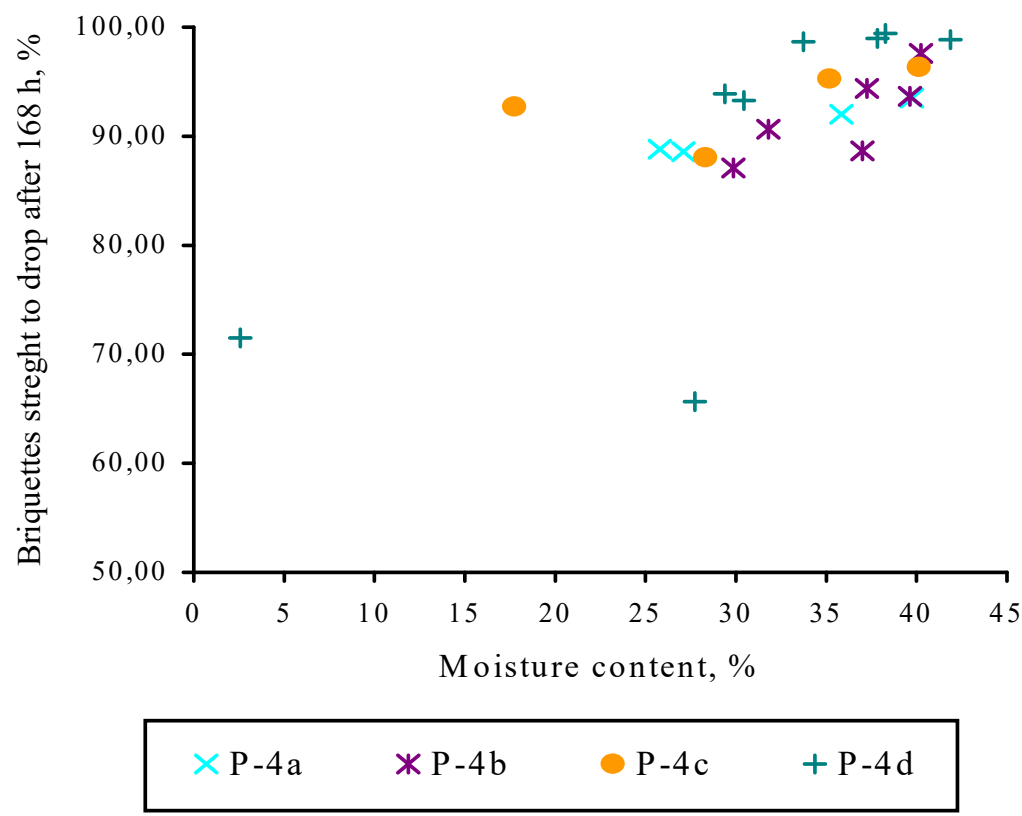

Fig. 6. Composite solid fuels briquettes strength to drop right after $168 \mathrm{~h}$.

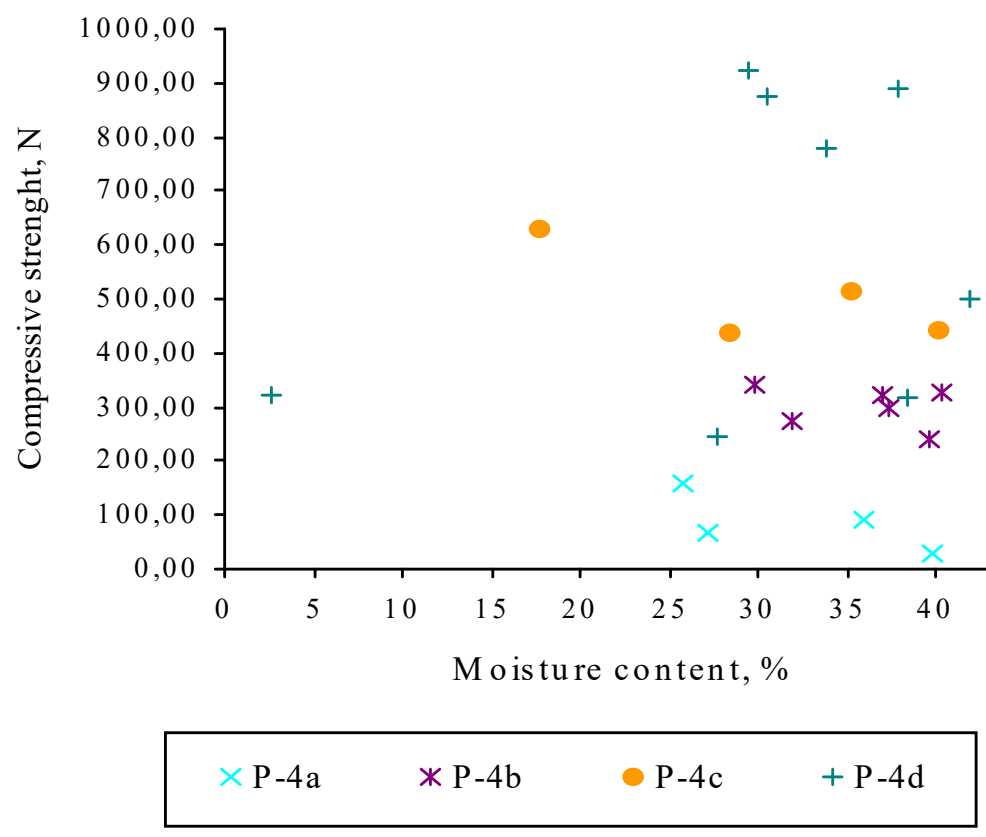

Fig. 7. Composite solid fuels briquettes' compressive strength after $168 \mathrm{~h}$. 
Table 3 presents the results of strength of the briquettes with the optimal moisture content.

Table 3. Results of strength testing of briquettes.

\begin{tabular}{|c|c|c|c|c|}
\hline Fuel & $\begin{array}{c}\text { Moisture } \\
\text { content, } \%\end{array}$ & $\begin{array}{c}\text { Strength to drop right } \\
\text { after the test, } \%\end{array}$ & $\begin{array}{c}\text { Strength to drop } \\
\text { after } 168 \mathrm{~h}, \%\end{array}$ & $\begin{array}{c}\text { Compressive strength } \\
\text { after } 168 \mathrm{~h}, \mathrm{~N}\end{array}$ \\
\hline P-1 & 27.5 & 93.1 & 93.3 & 472 \\
\hline P-2 & 35.0 & 0 & 88.44 & 174 \\
\hline P-3 & 0.1 & 88.18 & 88.47 & 312 \\
\hline P-4a & 35.0 & 91.56 & 92.01 & 90 \\
\hline P-4b & 40.0 & 95.90 & 97.58 & 325 \\
\hline P-4c & 40.0 & 94.60 & 96.32 & 444 \\
\hline P-4d & 37.5 & 97.55 & 99.42 & 989 \\
\hline
\end{tabular}

In most of the tries (apart from P-2) the briquettes directly after the compaction were characterised by drop strength of $K_{0}=88.18-97.55 \%$. After seasoning for 168 hours there was a marginal increase in the drop strength which equalled to $K_{168}=88.44-99.42 \%$. Compressive strength of the briquettes measured after 168 hours equalled $90-989$ N. The strength parameters were mostly determined by the moisture content of the material. The beneficial moisture content of fuels with binder (P1 and P2) and composite fuels ranged from $27.5 \%$ to $40 \%$.

As for hard coal (P-3), the favourable moisture content should be close to 0 . Fig. 8 presents the unit energy demand for the examined fuels which equalled to $Z_{\mathrm{e}}=7.65-12.85 \mathrm{kWh} / \mathrm{m}^{3}$.

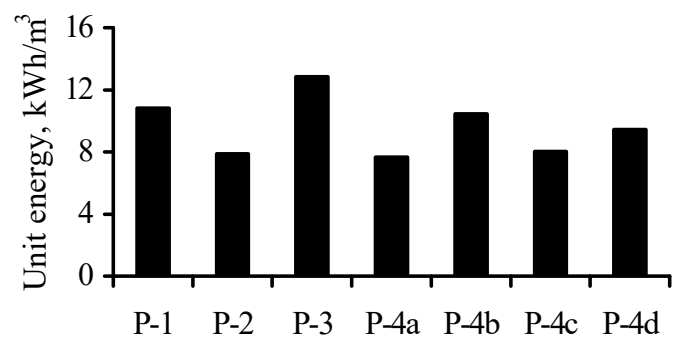

Fig. 8. Unit energy demand during briquetting determined for the tested solid fuels.

The highest torque on the shaft of a roll press was obtained with the lowest moisture content of the fuels which equalled to $3.5 \mathrm{kNm}$. The unit pressure on roll press' cavity forming rings of the roll press depended on the moisture content of the compacted material. In case of briquetting solid fuels with the moisture content of a couple per-cent it equalled to as much as $140 \mathrm{MPa}$.

\section{CONCLUSION}

In the roll press equipped with with asymmetrical layout compacting system and a gravity feeder fine lignite, fine charcoal, hard coal coke, coconut parings and composite fuels can be briquetted. The parameters of such briquettes are mostly determined by the moisture content of the material. Seasoning those briquettes for $168 \mathrm{~h}$ marginally increases their quality. Compressive strength of briquettes is closely connected with the type of compacted solid fuel.

There seems to be no direct correlation between the unit pressure on roll press' cavity forming rings and strength parameters of the briquettes. Based on the conducted experiments, the load on the shafts of the roll presses during the briquetting process was 
determined, which allowed for an update of the main drive of the roll press PW 500. The update is based on using the motor reducer Drive 6000 CHHMS75-6265-59/T F1250S/6 (i.e. electric motor with power equalling to $55 \mathrm{~kW}$ and nominal rotational speed $n_{\mathrm{n}}=980$ rpm and reducer type 'CYCLO' with gear ratio $i=59$ ). The rotational speed is controlled by the frequency converter FRA 540LG75KE1 (of Mitsubishi Electric). The roll press PW 500 scheme with the updated main drive is presented in Fig. 9.
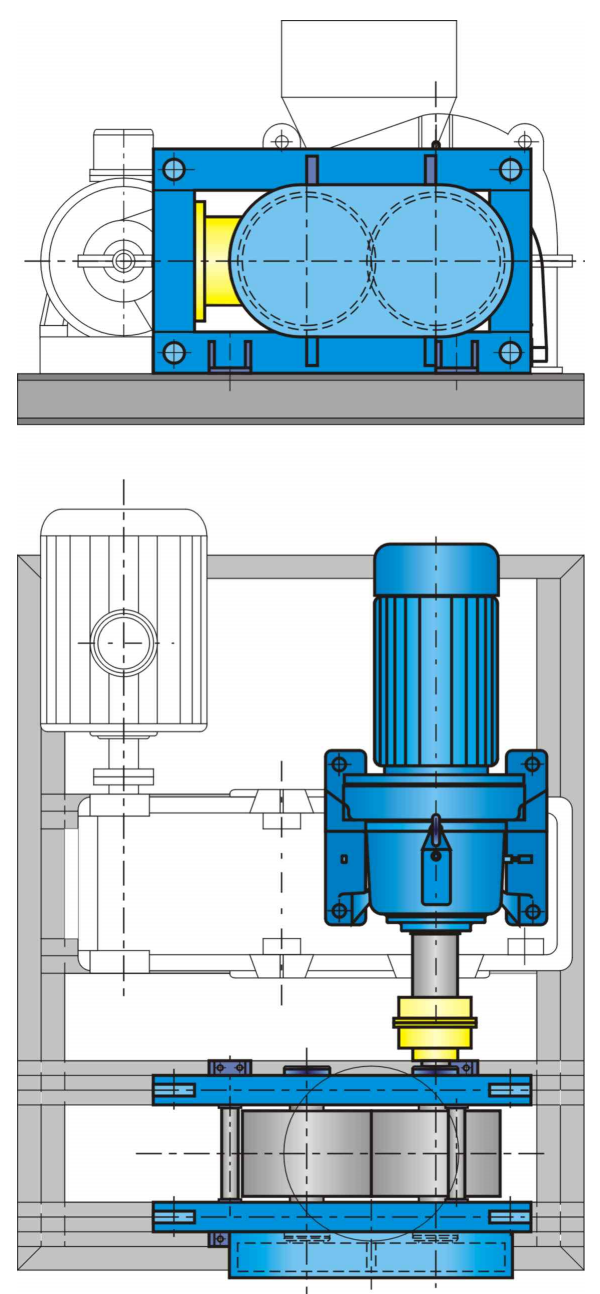

Fig. 9. Model of PW 500 industrial roll press before modernization and after modernization (color).

Acknowledgements: This article has been prepared within the scope of statutory activity, Contract No. 11.11.130.758. 


\section{References}

1. Projekt „Polityki energetycznej Polski do 2050 roku”. Opracowanie Ministerstwa Gospodarki, Warszawa 2015.

2. M. Tomaszewicz, G. Tomaszewicz, P. Babiński, J. Zuwała, Przem. Chem., 96(7), 1578-1584, (2017).

3. Directive 2009/28/EC of the European Parliament and of the Council of 23 April 2009 on the promotion of the use of energy from renewable sources and amending and subsequently repealing Directives 2001/77/EC and 2003/30/EC, OJ L 140, 5.6.2009, p. 16-62.

4. Program for Silesia, Elaboration of the Ministry of investment and development, Warszawa 2017.

5. B. Karwat, M. Nocuń, R. Machnik, J. Niedźwiedzki, Eksploat. Niezawodn. 18, 325, (2016).

6. B. Kosturkiewicz, A. Janewicz, A. Magdziarz, Pol. J. Environ. Stud., 23(4), 13851389, (2014).

7. B. Kosturkiewicz, A. Janewicz, M. Hryniewicz, P. Gara, M. Bembenek, Ł. Kosturkiewicz, Przem. Chem., 95(8), 1492-1495, (2016).

8. B. Kosturkiewicz, A. Magdziarz, M. Wilk, Rynek Energii, 5, 111-117, (2011).

9. B. Kosturkiewicz, A. Janewicz: Analysis of briquetting process of sewage sludge with coal to combustion process. E3S Web of Conferences, 10, art. no. 00041, 1-6, (2016)

10. B. Kosturkiewicz, A. Janewicz, M. Hryniewicz, Ł. Kosturkiewicz: Synthesis on research results of FGD gypsum briquetting. E3S Web of Conferences, 14, art. no. 02031, 1-10, (2017)

11. T. Dzik, M. Hryniewicz, A. Janewicz, B. Kosturkiewicz, Przem. Chem., 96(9), 18521855, (2017).

12. A. Janewicz, B. Kosturkiewicz, Przem. Chem., 94(9), 1521-1523, (2015).

13. A. Janewicz, B. Kosturkiewicz, Przem. Chem., 95(8), 1482-1484, (2016). 